\title{
The Accessibility of People with Disabilities to the Tourism Activities in Batu City
}

\author{
Ucca Arawindha $^{1}$, Titi Fitrianita ${ }^{1}$ \\ ${ }^{1}$ Sociology Department, Faculty of Social and Political Science, Brawijaya University, Malang, Indonesia \\ Correspondence: Ucca Arawindha, Jl. Veteran-Malang, 65145, Indonesia.
}

Received: November 30, 2017

Accepted: January 2, $2018 \quad$ Available online: January 5, 2018

doi:10.11114/ijsss.v6i2.2827

URL: https://doi.org/10.11114/ijsss.v6i2.2827

\begin{abstract}
This study aims at identifying the accessibility of people with disabilities to the tourism activities in Batu City. Batu is a city whose tourism industry develops so rapidly that it is called A Tourism City. Despite its mul tiple artificial and natural tourist sites, Batu City does not provide the accessible infrastructure for people with disabilities. According to the Local Regulation Number 7 Year 2011 about The Urban Planning of Batu City Year 2010-2030, the regulation about the disabled-friendly infrastructure is still minimum. It is only stated in Chapter 10 Section (4) m, explaining that the pedestrian lane is equipped with the walking lane for people with disabilities. However, if we refer to the Local Regulation of East Java Province Number 3 Year 2013 about Security and Service for People with Disabilities, every city/district is obliged to provide the accessible infrastructure for people with disabilities, including the accessible infrastructure in the tourist site. The accessibility is not limited to the walking lane for people with disabilities included in the Local Regulation of Batu City, but it also covers the toilet, parking area, hotel/inn, transportation, and etcetera. Consequently, this study is necessarily carried out due to the fact that the number of people with disabilities in Indonesia is quite many, as many as 37.5 million people (Wirawan, 2015). This study employs the Mix Methods. It is a survey method strengthened by the descriptive qualitative study. The data are obtained by using questionnaire, in-depth interview, observation, and document study. The finding of this study is expected to be able to give an overview about the readiness of Batu City as a Tourism City that is disabled-friendly, thus, it can be used as a basis of fair policy making for all citizens as well as to eradicate the discrimination, particularly in the tourism activities.
\end{abstract}

Keywords: accessibility, tourism, people with disabilities

\section{Introduction}

\subsection{Introduce the Problem}

Batu is a city in East Java Province, Indonesia whose tourism industry develops rapidly. It is located in $700-1700$ meters above the sea levels with temperature of $12-19$ degree Celsius. Enclosed by two big mountains, its topography consists of valleys. The fresh air, beautiful scenery, and high potential of natural tourist sites such as waterfalls, springs, and etc. make Batu one of the leading tourist sites of East Java Province.

Data from the Department of Tourism and Culture of Batu City show that the tourist visit to Batu City reached 3.5 million people in 2015 and it escalated to 3.9 million people in 2016. These data excluded the unrecorded tourist sites by the Department of Tourism and Culture, such as the apple picking tour. In 2017, it is targeted that 4.1 million people will visit this city (Agustina, 2017).

Along with its attempt to improve the local economy through the idea of comparative advantage by strengthening the tourism industry (Ashley, De Brine, \& Wilde, 2017), Batu City begins to develop the nature-based tourist sites to be the artificial-based tourist sites. Jatim Park, Secret Zoo, Batu Night Spectacular (BNS), Paralayang, Predator Fun Park, and etcetera are the artificial tourist sites that confirm Batu City as one of Tourism Cities in Indonesia. The attempt to develop the tourism sector is supported by the Central Government by the establishment of the National Tourism Development Plan Year 2010 - 2025 (RI, 2011). The Central Government even allocates the Special Allocation Funds to develop the local tourist sites.

Unfortunately, in the National Tourism Development Plan Year 2010 - 2025 the government does not develop the inclusive tourism. The Special Allocation Funds allocated to improve the accessibility and quality of the tourist sites 
through the facility and infrastructure developments (RI, 2015) does not consider the need of people with disabilities in accessing the tourist sites. They have the right to enjoy the tourist sites despite the fact that their rights are not fulfilled due to the infrastructure and social inhibitors (Bindu and Devi, 2016; Bordeianu, 2012; Popiel, 2016).

The policy to protect people with disabilities in Indonesia is under CRPD (Convention of Rights of Person with Disabilities) that is legitimated in November 2011. Regarding to the accessibility, the Law Number 4 Year 2007 about People with Disabilities has its own regulation. In Chapter 1 Article 1 Paragraph 4, it is stated that "the accessibility is an access provided for people with disabilities to create equivalency and opportunity in all aspects of life and living”. In East Java Province, there is the Local Regulation Number 3 Year 2013 about Safety and Service for People with Disabilities. However, this legal protection has not been well implemented.

\subsection{Explore Importance of the Problem}

Although the disability issue is not a new problem in Indonesia, its implementation is still very weak (Irwanto, 2010), including the establishment of the disabled-friendly tourism concept. According to Ahmad (Hartik, 2016), there is no tourist destination in Indonesia that provides special facilities for people with disability.

The big number of people with disabilities in Indonesia as many as 37.5 million people (Wirawan, 2015) does not make the government direct its concern to provide spaces that are accessible for them (Putri, 2011; Thohari, 2014). The low accessibility of people with disabilities to the tourist sites also occurs in other cities, such as Yogyakarta (Handoyo, 2017) and Bali (Adiningrat, Abdillah, \& Dewantara, 2015). The tour package and city infrastructure do not support people with disabilities to enjoy the tourist sites independently.

The low accessibility of people with disabilities to the tourist site leads to the more basic issue. The tourist site is a public space that becomes a place for individuals to interact with each other. The difficult access to the tourist site equals to reducing people with disability's access to the public space. Whereas, the opportunity to be present in the public space can be an attempt to reduce the negative view of communities to people with disabilities.

\subsection{Describe Relevant Scholarship}

Some studies have been carried out to see to what extent the inclusive tourist is implemented. Sammargaraja \& Wee (2013) state that Johor National Park in Malaysia does not provide enough facilities for visitors with disabilities. India also faces the similar problem. In India, the inclusive tourist has not been a significant issue to be taken into account by the government as the stakeholder, communities, and actors involved in the tourism industry (Ministry of Tourism, 2010).

For Bordieau (2012), developing the inclusive tourism is not the only attempt to be implemented as the social responsibility, but it also has a good business potential because it can reduce the tendency of the tourism seasonality. People with disabilities will get many benefits if the inclusive tourism is developed. According to Bindu and Devi (2016), people with disabilities are parties who have lack of access because of the low opportunity to access the tourism.

When the tourism industry has recognized the need of people with disabilities by providing services and creating special products for them, a new problem will raise. Unfortunately, the offered services and products are more expensive than the ones offered to people with no disabilities (Popiel, 2016).

\subsection{State Hypotheses and Their Correspondence to Research Design}

Regarding to the tourism industry and accessibility problem for people with disabilities, some countries such as USA and some European and Asian countries have implemented the Barrier-Free Tourism (BFT). In other words, it is a disabled-friendly tourism. Barriers can be defined as those impediments encountered while participating or attempting to participate in a tourism experiences (UN, 2003). Therefore, the Barrier-Free Tourism can mean an idea and practice of freedom to participate in the tourism activity or experience, including for people with disabilities; as based on the concept, people with disabilities also have the same need to go on touring/traveling.

Accessible tourism enables people with access requirements, including mobility, vision, hearing and cognitive dimensions of access, to function independently and with equity and dignity through the delivery of universally designed tourism products, services and environments. (Darcy, Cameroon, \& Pegg, 2010)

This study is initiated from the Barrier-Free Tourism idea. The survey about accessibility of people with disabilities to the tourism activity can be used as a basic research which is later employed as the tourism decision making of Batu City. Thus, it is expected that it can create a tourism model that is disabled-friendly. This survey is conducted in some tourist sites that become the city icons, such as Jatim Park I, Batu Secret Zoo, and Batu city square. The survey result is the accessible and non-accessible infrastructure mappings as well as their maintenance. 
The lack of research about BFT in Indonesia is shown from the few studies reviewing the relationship between people with disabilities and tourism. This study becomes one of the researches filling in the knowledge gap about accessibility of people with disabilities in Indonesia. In addition, this study is aimed to map the accessible locations in three tourist sites in Batu City. Through mapping, the accessibility level for people with disabilities will be identified, thus, the recommendation to create an inclusive tourism can be proposed to the government.

\section{Method and Technique of Data Obtaining}

This study employs the Mix Methods. It uses the quantitative and qualitative descriptive methods. The quantitative descriptive method is used because this study conducts the survey by using the questionnaire and it maps the accessible and non-accessible infrastructures. It also obtains citizens' responses about the disabled-friendly tourism in Batu City. The survey result will be supported by the qualitative descriptive method which attempts to understand the phenomenon occurred in the subject of the study (Moleong, 2007). The qualitative descriptive method is used to interpret the quantitative data. It describes the meaning of numbers and digs the depth of the problem found in the field to sharpen the data analysis.

In the quantitative method, this study employs the concept to derive the research variable and indicators. The derivation of the operational definition of the research variable is as follows.

Table 1. The Operational Definition of the Research Variable

\begin{tabular}{|c|c|}
\hline Research Variable & Research Indicator \\
\hline The disabled infrastructure accessibility level & $\begin{array}{l}\text { Tourism information } \\
\text { The access to reach and enter the tourist site } \\
\text { Tourism facility usage } \\
\text { Tourism service }\end{array}$ \\
\hline The disabled infrastructure accessibility response & $\begin{array}{l}\text { Response to the information access } \\
\text { Response to the access to reach and enter the tourist site } \\
\text { Tourism facility usage } \\
\text { Response to the tourism service for people with disabilities }\end{array}$ \\
\hline
\end{tabular}

Source: Kurniawan, 2005.

The data are obtained in 3 (three) different tourist sites, namely Jatim Park 1, Batu Secret Zoo, and Batu city square. The data are obtained through observation, interview, and document study. The observation carried out in this study is a passive participation observation in which the researcher comes to the informant's place without directly involving in the activities (Sugiyono, 2010). The researcher observes the object of the study, namely the infrastructure of the studied tourist sites. In addition, the interview is carried out in two ways, namely the structured interview by using the questionnaire and the semi-structured interview by using the interview guide. The semi-structured interview is intended to the tourists who visit the tourist site, tourist manager, representative of the Department of Tourism and Culture of Batu City, as well as people with disabilities. The document studied is the data about people with disabilities as well as tourism in the Department of Tourism and Culture of Batu City.

The respondents are chosen by using Random Sampling. Referring to Slovin formula, there are 97 samples. The next technique used is the Incidental Sampling. It is based on the occurrence of unintentional meeting with respondents who fit the data source (Sugiyono, 2010). The samples are tourists in the studied tourist sites.

The data are analyzed by using SPSS software. Thus, the data are shown in the form of percentage description with a frequency table. The qualitative data are analyzed by using reduction, display, and verification methods.

\section{General Overview of the Tourist Sites in Batu City}

\subsection{Batu Secret Zoo}

Batu Secret Zoo is a zoo located in Batu City. Its location is in Jatim Park Group tourism setting. It is 14 hectares width and it began its development in 2008. In June 2010, it was opened by the President, Susilo Bambang Yudhoyono.

Batu Secret Zoo's concept is a modern zoo completed with attractive rides, such as flying lemur, aquarium, flamingo, elephant, and hippo croc garden, eagle, safari farm, gorilla, bear, and tiger lands. In addition, there is a Fantasy Land with 20 fun rides as well as Kidzone which provides a lot of rides for children. It is the first modern zoo in Indonesia. It also provides some public spaces for its visitors. Batu Secret Zoo is not only a casual zoo, but it also a place to learn about animals, like its motto "Animal learning and recreation."

When entering the zoo, there will be a ticket counter which looks like a tree root and it is integrated to the building which looks like a tree namely Pohon Inn Hotel. In the zoo, the visitors can see a lot of animals originally from Indonesia as well as other animals from foreign countries, such as kangaroos and so on. 
The route of Batu Secret Zoo is made as comfortable as possible for its visitors, so they do not need to be afraid of missing the part of the zoo because there are clear direction signs and helpful staffs along the route. Moreover, the visitors can rent e-bikes worth 100 thousand rupiahs per three hours per person. When the visitors are hungry or thirsty, they can buy food and drink in Rimba Café and African Market.

Every cage and crib is completed with the information about the animals' Latin and Indonesian names as well as the animals' extinction rates, so the visitors can get information about the animals they are watching. The manager also facilitates the visitors with visual aids to memorize the animals' names. However, the visual aids are not equipped with the letters that can be accessed by people with disabilities (such as braille letters for those who cannot see).

In the African ride, there is a glass tunnel called Savannah. Inside the glass tunnel, there are many beasts originally from Africa, such as Giant Sable Antelopes, Scimitar-Horned Oryx, and Zebras. There are some small animals as well, such as meerkats, guinea pigs, rabbits, and so on. Big-beaked birds can also fly freely above the visitors' head. In addition, some zebras and ostriches become the inhabitants of the Savannah that is designed like the Inner Africa. In this zoo, there is the first white lion in Indonesia. The visitors can feed them.

Besides going around the zoo to watch the animals, the visitors can also enjoy some rides. The ride that the visitors should not miss is the River Adventure. The visitors take boats along the river while watching orangutans. There are also some attractive rides such as water rides called Log Flume, Feeding Birds, and Fantasy Land that are worth trying.

\subsection{Jatim Park I}

Jatim Park I is located in Kartika 2 Street, Batu City. It is near other tourist sites, such as Museum Angkut, Eco Green Park, Batu Secret Zoo, and Batu city square. This tourist site integrates the tourism and education. It is built on one-hectare land in the west slope of Panderman Mountain. It is located on 850 meters above the sea level, so it offers beautiful view and cool air for the visitors. With One Stop Service concept, it welcomes the visitors from 08.30 a.m. to 4.30 p.m. every day.

When the visitors enter Jatim Park I area, they will enjoy the museum of body. It is the only and the most complete museum of body in Indonesia. In the initial route, the visitor will enjoy Nusantara Ethnic Gallery and East Java Pavilion that will bring the visitors to the hallway of time. The visitors can explore the various Indonesian cultures and learn about them. There is also a Learning Gallery (chemistry, physics, biology, and mathematics) with a Learning Gallery Stadium that can fit to 300 students. After visiting the education section in the initial route, the visitor will enjoy the entertaining and thrilling rides. There are some rides such as roller coaster, flying tornado, drop zone, and so on. If the visitors do not want to enjoy the rides, they can go to the swimming pool. Jatim Park I also offers other things, such as fruit, animal, and vegetable markets.

Jatim Park I also provides some facilities, such as a mosque, toilets in 14 places with total 60 restrooms, wheelchair and baby stroller lane, wheelchair rent, health clinic, rest area for baby and mother, breastfeeding room for mother equipped with microwave, dispenser, and diaper changing area, as well as one-hectare parking area. In the health clinic, there are some staffs who are ready to serve from 8 a.m. to 4.30 p.m. every day. In addition, the toilets are equipped with the special toilets for people with disabilities, particularly for those who are using wheelchair.

\subsection{Batu City Square}

Batu city square is located in the center of the city. It was built in 1850ish and renovated in 2011. The renovation is done in order to make it more family-friendly. The facilities are children-friendly and they utilize the open spaces. They can be used to interact with each other while enjoying the atmosphere. The city square was first built as the icon of Batu City that produced apples, so an apple monument was built. After that, some facilities and green spaces were developed to be used as the family recreational place.

Based on the information from the city square manager, the development of the city square was adjusted to the mayor ruling the city. The one thousand-flower park was developed before Mayor Edy Rumpoko ruled the city. In his period, Mayor Edy Rumpoko changed the city square to be a park and an icon of Batu City that can be enjoyed by all citizens, namely children, young adults, and elderly people.

There are some artificial objects like animals and fruits in some corners of the city square. There are also several lampions with the shape of cow, rabbit, apple, and orange. They are used by the visitors to take pictures with. The city square is located in the little steep landscape. However, based on the researcher's observation, this loc ation does not give difficulties to people with disabilities because the lane is accessible by wheelchairs and there is a rocky lane which helps people who cannot see walk.

\section{Accessibility of Tourism Infrastructure in Batu City}

Based on the data analysis by using the Statistic Package for Social Science (SPSS), 69.1\% of the tourist infrastructure 
in Batu city square, Jatim Park 1, and Jatim Park 2 was moderately accessible, whereas $30.9 \%$ of the tourist infrastructure was highly accessible.

The percentage of the accessibility was affected by one indicator, namely the access to tourism information that could only be accessed by some visitors with disabilities and visitors who could not see. The information tended to be difficult to be accessed by visitors who could not hear. The special direction signs for visitors who could not see was not available. The information for visitors who could not hear could only be obtained from the voice announcement. Based on the data analysis by using SPSS, the tourist information accessibility was low, only $50.5 \%$. This could be shown from the statistical data analysis as follows.

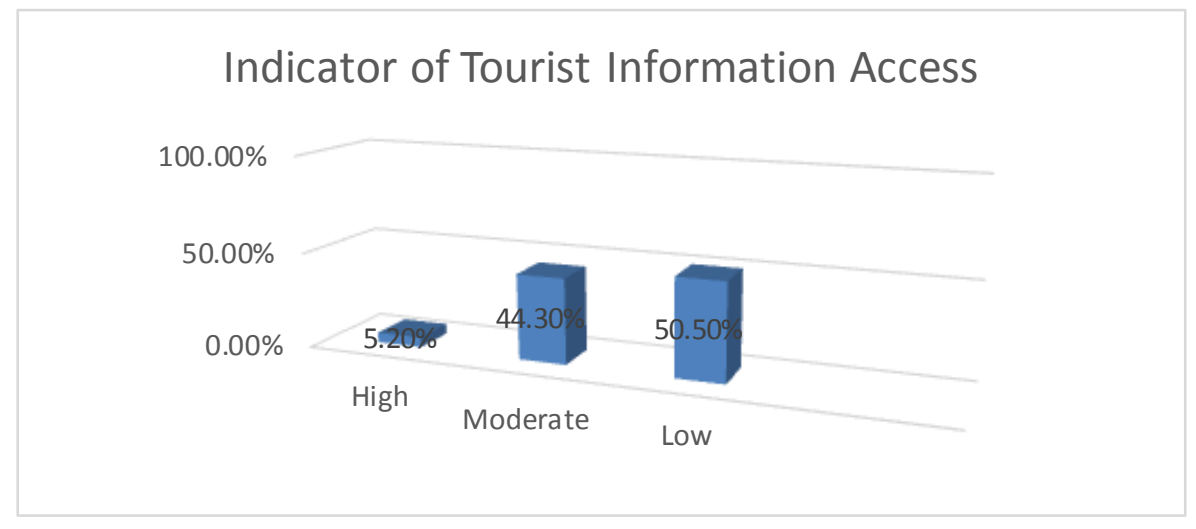

Source: Primary Data, 2017.

The accessibility of the tourism infrastructure was also affected by the easiness to reach and enter the tourist site. The route in the tourist site was mostly wheelchair-friendly. However, only a few special lanes -the rocky lane-- were built for visitors who could not see. Another access that could be used by those who could not see was the handle in the side of the path. The distance between facilities in the tourist sites was also reachable for visitors with disabilities. However, the tourist sites did not provide special transport for visitors with disabilities. According to the respondents, the entrance gate tended to use the automatic door or wide door, so it was easier for visitors with disabilities. Another concern was that the ticket counter and special queue for those with disabilities were not widely available. This was supported by the graphic of the statistical data analysis below. The indicator of the easiness to reach the tourist site was low, as much as $45.4 \%$.

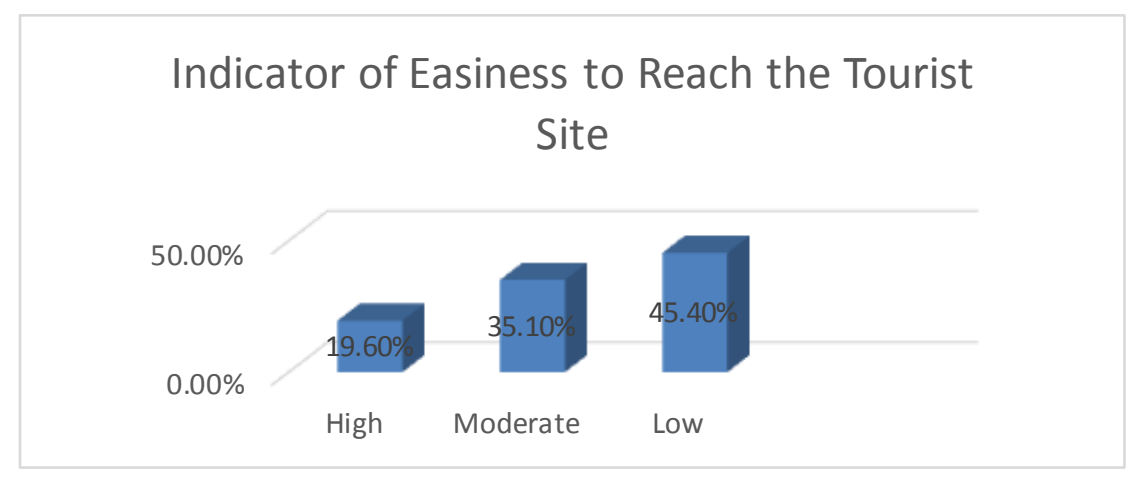

Source: Primary Data, 2017.

Another indicator that affected the accessibility of the tourism infrastructure was the tourism facility usage. There were a few facilities that could be used by visitors with disabilities. Based on the researcher's observation, the tourism facilitie s that could be used by visitors with disabilities were the public facilities, not including the rides. According to the respondents, the public facilities such as special toilets and special sinks were not available yet and the available facilities could not be fully utilized by visitors with disabilities.

"Most of the toilets are inaccessible, but the newer tourist site like Museum Angkut (Jatim Park 2 block), if I'm not mistaken, is more accessible. However, they do not consider that people with wheel-chairs need more space. Consequently, the door (the toilet door) cannot be closed. So, if we are not adept to use the wheel chair, we will get difficulty entering the toilet." (Primary Data, 2017).

The special parking area was also not used by visitors with disabilities. Even so, some respondents explained that there was a special rest area for visitors with disabilities. 
The tourism service also affected the accessibility of people with disabilities to the infrastructure in the tourist sites. The tourism service included the convenience during visiting the tourist sites. According to the majority of respondents, the studied tourist sites were convenient for visitors with disabilities. However, there were only a few staffs available to assist visitors with disabilities. Based on the respondents' explanation, visitors with disabilities were assisted by their relatives. Some respondents stated that the staffs were friendly. Even so, some visitors with disabilities said that the staffs needed a special training to assist visitors with disabilities.

"There is a need to held a kind of training (for the staff) to assist our friends with disabilities" (Primary Data, 2017).

Tourism became one of the economic sectors that developed rapidly and became a big sector nowadays (ILO, 2009). The tourism sector contributed significantly to the economic growth of a region and a country. Due to the promising potential, there were many cities in Indonesia using their places as a tourism destination and offering many types of entertainment, either the natural or artificial tourism or the integrated one.

According to the data obtained from the Ministry of Tourism and Creative Economy, the tourism sector was one of the five biggest income contributors in 2009 to 2013 along with oil and gas, coal, palm oil, and processed rubber (RI, 2005). Moreover, the tourism industry sector was one of the industry sectors that was not influenced by the uncertainty of the global economy. Therefore, the government stimulated the growth of the tourism industry amidst the uncertain commodity price in the global market.

The government's concern to develop the tourism as an industry was shown from the Special Allocation Fund Year 2016 allocated to improve the accessibility of citizens to the tourist sites (Special Allocation Fund in the transport field) and improve the quality of the tourist sites by de veloping facilities through tourist sites arrangement (Special Allocation Fund in the tourism field) (RI, 2005). Unfortunately, the government's seriousness to improve the accessibility of citizens has not included citizens with disabilities as the part of citizens who potentially accessed the tourist sites.

As one of the cities with rapid tourism development, the government of Batu City as well as the central government have not considered the visitors with disabilities when they de veloped the tourism facilities. The Barrier-Free Tourism concept that offered inclusive tourism ideas for visitors with disabilities has not been familiar to the government of Batu City despite the fact that the government of Batu City was open to suggestion to develop the inclusive tourism for those with disabilities.

In the de velopment of tourism in Batu City, the Department of Tourism tended to focus on how to attract more investors to invest their money to the development of the artificial tourism by the reference of Mayor Edy Rumpoko. In carrying out their duty, the Department of Tourism of Batu City guaranteed the policy implementation to obtain the license of tourist site development (bureaucracy shortcut). They also guaranteed the legal certainty, citizen's acceptance, as well as tax deduction for tourism business actors.

The Department of Tourism's focus on the policy development was reflected on their attempt with the regional government to establish two Local Regulations in the last ten years. First, it was the Local Regulation Number 1 Year 2013 about the Tourism Organization of Batu City. Second, it was the Local regulation Number 1 Year 2014 about the Preservation of the Cultural Heritage. In those two regulations, there was no disability issue covered by Batu City government.

The Department of Tourism of Batu City recognized that they have not prioritized visitors with disabilities assessing the tourism object. The tourism facility development in Batu City has not been concerned about the needs of visitors with disabilities. For example, the extreme rides in the artificial tourist sites were only intended for visitors with no disabilities. The owner and manager of tourist sites in Batu City were not "forced" to provide the disabled-friendly facilities as the concern about it in the tourism development was very minimum.

Despite the fact that the local government represented by the Department of Tourism of Batu City did not have a set of policy for visitors with disabilities, some managers and owners of tourist sites have developed their own disabled-friendly facilities. For example, Jatim Park I was not designed with stairs, but rather with sloping path. It also provided wheelchair, electric scooter, and special toilet for those with disabilities, as well as guides assisting visitors with disabilities. The more disabled-friendly facilities in Jatim Park I have been established in the last four years.

However, some tourist sites have provided the accessible facilities that were not accessible enough for visitors with disabilities (Popiel, 2016). It was quite impossible for visitors with disabilities to enjoy all tourism activities and products. For example, in spite of the sloping path, the up and down landscapes of Batu City made some visitors with disabilities need more energy to walk or pass through it. Another example was the extra energy to push the wheelchair despite its availability in the tourism places.

The special toilet for visitors with disabilities also raised problems due to the slippery floor and the absence of handle. 
Another problem was the toilet was not wide enough for visitors with wheelchair, so they found difficulty in closing and opening the toilet door. The worship place was one of the places that was not disabled-friendly because the floor in the ablution room was slippery, so it was dangerous for visitors with disabilities. In addition, there was no ramp to facilitate visitors with disabilities to go to the mosque.

Furthermore, the staffs have not been trained to assist visitors with disabilities. The lack of knowledge about how to assist the visitors with disabilities made their service minimum. Due to the absence of training, the staffs could only re ly on their little knowledge to assist the visitors with disabilities. Whereas the trained staffs would make the accessibility of the visitors with disabilities higher.

The owner and manager of Jatim Park have focused on how to provide facilities and infrastructures for visitors with disabilities despite its minimum result. There were many types of disabilities other than the physical disabilities, namely the sensory disabilities (visitors who could not see, hear, and mentally disabled) and mental disabilities. There was no infrastructure developed by the owner and manager of Jatim Park for all types of disabilities. There was no guiding block for those who could see as well as sign languages in the public facilities, such as in animal shows and helping text facilities in the information places.

However, their attempt to provide the facilities and infrastructures for visitors with disabilities was highly appreciated. Unfortunately, there was no accurate and proper information for visitors with disabilities about the easy access for them. The information about the facilities and infrastructures in the tourist site was also poor.

The owner and manager of Jatim Park seemed passive to provide the service for visitors with disabilities. Generally, the development of facilities and infrastructures were based on the visitors' request put in the suggestion box. When there was no request from visitors with disabilities, the owner and manager of the tourism object would not provide the disabled-friendly facilities and infrastructures. Similar to the Department of Tourism of Batu City, the manager of Jatim Park had no idea about the Barrier-Free Tourism's concept. This made them unable to actively develop accessible facilities for visitors with disabilities.

The government's monitor to Jatim Park was done by doing a visit every weekend and holiday to check if there was a problem in their management. The government never checked if the facilities and infrastructures of the tourist site have been disabled-friendly because it has not been their concern yet. Thus, the owner and manager of tourist sites only provided the facilities and infrastructures for visitors with disabilities based on their recognized needs or request put in the suggestion box.

The similar thing was found in Batu city square. From the observation in Batu city square and interview with the manager, it was identified that there was no tourism facility particularly established for visitors with disabilities. Some facilities such as water fountain, playground, and Ferris wheel were not particularly designed for visitors with disabilities. Even some roads were blocked by portals, so it was difficult for them to go through.

The toilet in the city square area was not equipped with special facilities for visitors with physical disabilities. Moreover, the mosque in the city square area was too far to be accessed by visitors with physical and sensory disabilities. Its ablution room was out of their reach. The worship place provided by some restaurants near the city square was also difficult to access because it was in the second floor and it took some effort to go upstairs to reach it.

The city square's manager stated that the tourism setting in the city square was fully the government's policy and supervised by the Department of Environment. The city square was designed by the local government and supervised by Mayor Edy Rumpoko. It was intended to be Batu City's icon after building the apple monument in the center of the city square. It was designed to be an affordable tourist site that was accessible for all citizens, yet it put aside the accessibility for visitors with disabilities.

In the interview section, the manager explained that some visitors with disabilities have visited the city square. There was no special staff in charge to assist them because they had come with their own relatives who helped them to access the city square area. There were some operators and staffs in charge to run and monitor the Ferris wheel as well as assist visitors with disabilities if they wanted to go on it. However, they were not well-trained to assist visitors with disabilities, so their own relatives still became the major help for them.

Similar to the local government of Batu City that designed the tourist site with minimum awareness of visitors with disabilities, the city square's manager was not aware of developing more disabled-friendly and accessible city square. In fact, the city square's manager has communicated intensively with the local government of Batu City about the facilities and infrastructures. However, the issue about the visitor with disabilities was still out of their topic.

The Barrier-Free Tourism's concept was still unfamiliar to the city square's manager. The inclusive tourism has not been a concern of the local government and tourist sites' managers in Batu City. Despite the fact that the inclusive tourism has been long declared, the disabled-friendly tourism has not been a main practice which became the guide for the 
stakeholder to develop the tourism in Batu City. Even the city square's manager still pitied people with disabilities, not seeing them as people with limited space because of lack of accessibility.

The inclusiveness of tourism for people with disabilities was an important concern because fulfilling the recreational need was a basic need of human beings. The problem of accessibility and the stigma of low economic condition were the fundamental problems which led to the absence of people with disabilities' right in the tourist sites. They were not considered as the tourism target market that were potentially involved.

According to Smith (Bindu and Devi, 2016), there were three elements encountered by people with disabilities when accessing the tourist sites. First, the environment including the architectural and ecological factors. Second, the communicative barrier. Last but not least, the intrinsic barrier including the psychical, psychological, and cognitive abilities. Those three elements became a layered barrier for those with disabilities when accessing the tourist sites despite the fact that the level of barrier depended on the types of disabilities (Popiel, 2016). As explained by Smith (Bindu and Devi, 2016), the first barrier was the intrinsic barrier. The psychical, psychological, and cognitive abilities of people with disabilities became the first factor determining if they were willing to visit the tourist sites or stay at home because encountering people who had no idea how to treat people with disabilities well was not an easy matter. Therefore, visiting the tourist sites was not merely a physical movement, but it required a strong mental condition. When they were not internally ready to visit the tourist sites, recreation was impossible to do.

The next process was the communication barrier with people around the tourist sites. The interpersonal communication involved family, friends, neighbors, and colleagues. If the communication and understanding were not well-established, the willingness to visit the tourist sites would not be achieved despite the encountered intrapersonal barrier. This was regarding to the fact that people with disabilities were unable to visit the tourist sites by themselves, so communication with people around them as their assistant was absolutely required.

The last barrier was the infrastructure barrier. Even though this was the last barrier, the participation of people with disabilities to access the tourist site was determined by this factor. Thus, the infrastructure accessibility was an important factor to be taken into account so that the tourist sites became inclusive and accessible for anyone, including those with disabilities.

For those with disabilities, the very first thing to consider before visiting a tourist site was its accessibility. Their willingness to visit the tourist site was as high as the willingness of people with no disabilities (Bindu and Devi, 2016). However, the accessibility barrier made those with disabilities prepared more. Siska, a person with physical disabilities, stated that she has been to some tourist sites in Batu City, such as BNS, Jatim Park I, and Eco Green Park.

Private or rented transportation was more preferable than the public transport. The public transport was ne ver favorable because it was difficult for people with disabilities to get into the vehicle and put their wheelchair in. In addition, going with family or friends was also more preferred than going by the public transport and meeting many strangers on the way. This way of travelling was an attempt to reduce the interpersonal and intrapersonal barriers of people with disabilities.

Being in the crowd of people they knew and those who understood how to treat them made people with disabilities more confident to react to strangers who looked at them with strange look. When the intrapersonal barrier was resolved and the interpersonal support was gained from the surrounding, the strange look given by other visitors in the tourist sites would not matter, so the psychical pressure could be resolved.

Siska, a person with physical disabilities, explained that the artificial tourist sites such as Jatim Park I, Eco Green Park, and BNS could be enjoyed easily by visitors with physical disabilities who used wheelchair. Although they had to be assisted in some points because the path was going up, she rated that the tourist sites were convenient for people with physical disabilities.

Almost all parts of Eco Green Park could be accessed by visitors with physical disabilities. While in Jatim Park I, the extreme rides could not be accessed by them. The mini theater in Jatim Park I could be easily accessed because the manager provided different doors for visitors with disabilities. Other visitors could use the spinning door which was impossible for those with wheelchair to use it.

Among all facilities provided in the tourist sites, the toilet was the first facility to be examined by visitors with disabilities. It was because the toilet was barely well-accessed by them. The problem was there was no special toilet for visitors with disabilities or the toilet's structure was not disabled-friendly. Some rides in the tourist sites could not be enjoyed by those with disabilities because they were too extreme and visitors with disabilities did not meet the safety requirement.

The restaurant in the tourism place was well-accessed by visitors with disabilities. While the toilet and mosque were two facilities that were difficult to access. The ticket counter was sometimes not accessible because it was too high to 
reach. And although visitors with disabilities could buy the ticket themselves, they could not do it because the counter was out of their reach.

It was recognized that visitors with disabilities were well-assisted by the staffs. However, Siska stated that they were not accustomed to assist visitors with disabilities, so they could not measure how far the assistance was required. In some cases, some visitors with disabilities seemed to need an assistance from the staffs, but they did not want to be helped. This made the staffs wait for the request rather than actively help.

The staffs' knowledge about which facilities fully accessible for visitors with disabilities was very important to acquire for the sake of visitors' convenience. By their knowledge, visitors with disabilities could enjoy their visit in the tourist sites. This could not be done if the owner or manager of tourist sites were not aware of visitors with disabilities.

The owner and manager's concern about visitors with disabilities in the Barrier-Free Tourism's concept was not a social responsibility. Visitors with disabilities were the potential target market due to their abundant number. The data obtained from the Central Bureau of Statistics of Indonesia showed that in 2010, there were 9,046,000 people with disabilities out of 237 million citizens (Fachrudin, 2015). This number was a big potential as people with disabilities would take their families as their assistant, so they would spend more money on the tickets than people who could access the tourist site independently.

The potential to develop the tourism industry targeting visitors with disabilities has been a concern in some developed countries, such as USA and Germany. The developing countries have not taken this issue into account. Similar to Indonesia, Romania (Bordeianu, 2012) was a de veloping country with high tourism potential, yet its concern about visitors with disabilities was very low. Without legality which became the ultimate requirement to develop the barrier-free tourism (Cameron, Foggin, \& Darcy, 2003), the disabled-friendly tourism was difficult to achieve.

\section{Tourists' Responses to the Tourism Infrastructure in Batu City}

The measured response included the response to the information accessibility, the easiness to reach and enter the tourist site, as well as the response to the facility usage and services for people with disabilities. It could be seen that most respondents thought that the infrastructure accessibility in Jatim Park 1, Jatim Park 2, and Batu city square was considered moderate, as much as $78.4 \%$.

The response to the infrastructure accessibility was affected by the easiness to access the information by visitors with disabilities. In addition, it was also influenced by how accessible the path by visitors with disabilities. The majority of the respondents considered that the tourism information was well-accessed by visitors with disabilities. The same respondents also explained that the path was easy to use by visitors with disabilities. Similar opinion was also given for vehicle used by visitors with disabilities to go around the tourist sites.

Nevertheless, some respondents in the tourist sites suggested that visitors with disabilities should have been assisted by communicative and responsive staffs. They also advised that the vehicle used to go around the places was adjusted so that it was accessible for visitors with wheelchair, particularly in Jatim Park I and Batu Secret Zoo.

Another indicator influenced the infrastructure accessibility's response was the tourism facility usage and service for visitors with disabilities. Some respondents thought that some facilities in the tourist sites were well-used and accessible by visitors with disabilities. However, some said differently. This was because some facilities, particularly the toilet and worship place, were still difficult to access by visitors with disabilities. This was particularly found in Bat u city square. Some public facilities in Jatim Park I and Batu Secret Zoo were accessible by visitors with disabilities. According to the respondents' responses, the service given to visitors with disabilities was quite good. Nevertheless, almost all respo ndents stated that visitors with disabilities required special services.

\section{Conclusion}

The study about Accessibility of People with Disabilities to the Tourism Activities in Batu City results in some findings. From the field observation, it is found out that the infrastructure accessibility of people with disabilities to the tourism activities is moderate. It means that there are some inaccessible infrastructures for people with disabilities in the tourism activities.

The observation in three different places, namely Jatim Park I, Batu Secret Zoo, and Batu city square finds that some facilities in the tourist sites have been accessible by visitors with disabilities, such as some special toilets, the sloping path that is accessible for wheelchairs, as well as the health clinic that operates for 24 hours. While some other facilities, such as parking area, ticket counter, worship place/mosque, public transport, hotel, and information board are inaccessible for visitors with disabilities.

The inaccessible tourism infrastructure for people with disabilities is caused by the absence of government's concern and people in general about the importance of tourism that is friendly for all, including those with disabilities. There should be 
an understanding that everyone has a right to access the tourism activity as one of the recreational needs, including those with disabilities. In addition, there is no regulation in Batu City that regulates tourist sites' owner or investor to provide accessible facilities for all. This is a kind of irony as Batu City is called the Tourism City, but it has no policy ruling about the comprehensive and accessible tourism management.

The Barrier-Free Tourism concept that is implemented in some developing country can be a solution for the tourist infrastructure inaccessibility for people with disabilities in Batu city in particular and Indonesia in general. However, the Barrier-Free Tourism adoption has to be done step by step, regarding to the fact that there has been no firm policy in Indonesia to regulate the accessible tourist sites for people with disabilities. In addition, people's awareness about rights of people with disabilities is still low.

\section{References}

Adiningrat, G. P., Abdillah, Y., \& Dewantara, R. Y. (2015). Kualitas Pelayanan Bagi Wisatawan Berkebutuhan Khusus (Disabilitas) di Hotel Berbintang Lima. Jurnal Administrasi Bisnis, 1-7.

Agustina, S. (2017). Retrieved from travel.tribunnews.com: https://www.google.co.id/amp/travel.tribunnews.com/amp/2017/04/08/pemkot-kota-batu-targetkam-kunjungan-wis ata-tahun-ini-41-juta-pengunjung

Ashley, C., De Brine, P., \& Wilde, H. (2007). The Role of the Tourism Sector in Expanding Economic Opportunity. Cambridge: Harvard University.

Bindu dan Devi, K. (2016). Accesible Tourism : Determinants dan Constraints ; A Demand Side Perspective. Journal of Bussiness and Management, 8(9), 1-8.

Bordeianu, O. M. (2012). Accessible Tourism - A Challange for Romanian Tourism. Journal of Tourism, 42-48.

Cameron, B., Foggin, B., \& Darcy, S. (2003). Towards Barrier Free Tourism : Initiatives in the Asia Pasific Region. Travel and Tourism Research Association Canada Conference (pp. 1-14). New Brunswick: Saint John.

Darcy, S., Cameroon, B., \& Pegg, S. (2010). Accessible Tourism and Sustainability: A Discussion and Case Study . Journal of Sustainable Tourism, 515-537. https://doi.org/10.1080/09669581003690668

Handoyo, F., \& dkk. (2017). Paket Wisata Bagi Difabel di Yogyakarta. Jurnal Pariwisata Terapan, 116-128.

Hartik, A. (2016). Retrieved from kompas.com: https://www.google.co.id/amp/s/app.kompas.com/amp/travel/read/2016/09/28/054205227/destinasi.wisata.indonesi a.belum.ramah.terhadap.kaum.difabel

ILO. (2009). Implication of Global Economi Crisis for Tourism Emplyoment : Case Study for Indonesia. Jakarta: ILO Jakarta Office.

Irwanto, d. (2010). Analisis Situasi Penyandang Disabilitas di Indonesia : Sebuah Desk Review. Jakarta: AusAid.

Kurniawan, H. (2015). Potret Aksesibilitas Infratsruktur Bagi Difabel. Jurnal Difabel, 2(2), 278.

Moleong, L. J. (2007). Metodologi Penelitian Kualitatif. Bandung: PT. Rosdakarya Offset.

Mopecha, N. B. (2016). Barriers to People with Disabilities in the Tourism and Hospitality Industry : A Case Study of Buea in South West Region of Cameroon. Gazimagusa: Eastern Mediterranian University.

Popiel, M. (2016). Tourism Market, Disability, and Equality : Problems and Solutions. Krakow: Institute of Geography and Spatial Management.

Putri, G. H. (2011). Aksesibilitas Difabel Dalam Ruang Publik. Surakarta: digilib.uns.ac.id.

RI. (2011, Desember). Peraturan Pemerintah Republik Indonesia Nomor 50 Tahun 2011 Tentang Rencana Induk Pembangunan Kepariwisataan Nasional Tahun 2010-2025. Jakarta.

RI, D. (2015). Industri Pariwisata : Alternatif Sektor Andalan di Tengah Pelemahan Ekonomi Domestik. Jakarta: Biro Analisa Anggaran dan Pelaksanaan APBN Setjen DPR RI.

Sanmargaraja, S., \& Wee, S. T. (2013). Constraint of Alternative Tourism in Malaysia. International Journal of Advances in Management, Technology and Engneering Sciences, 9-13.

Sugiyono. (2010). Metode Penelitian Kuantitatif dan Kualitatif. Bandung: Alfabeta.

Thohari, S. (2014). Pandangan Disabilitas dan Aksesibilitas Fasilitas Publik bagi Penyandang Disabilitas di Kota Malang. Indonesian Journal of Disability Studies, 27-37.

Tourism, M. O. (2010). Problemand Prospect of Accessible Tourism in India. Govindpuri: Indian Institute of Tourism and 
Travel Management.

UN. (2003). Barrier Free Tourism For people With Diisabilities in The Asian and Pacific Region. New York: United Nations.

Wirawan, O. A. (2015, Maret 24). Retrieved from beritajatim.com: www.beritajatim.com/politik_pemerintahan/2343/pelaksanaan_perda_difabel_jatim_masih_mengecewakan.html

\section{Copyrights}

Copyright for this article is retained by the author(s), with first publication rights granted to the journal.

This is an open-access article distributed under the terms and conditions of the Creative Commons Attribution license which permits unrestricted use, distribution, and reproduction in any medium, provided the original work is properly cited. 